\title{
Gamma delta TCR anti-CD3 bispecific molecules (GABs) as novel immunotherapeutic compounds
}

To cite: van Diest E, Hernández López $P$, Meringa AD, et al. Gamma delta TCR anti-CD3 bispecific molecules (GABs) as novel immunotherapeutic compounds. Journal for ImmunoTherapy of Cancer 2021;9:e003850. doi:10.1136/ jitc-2021-003850

- Additional supplemental material is published online only. To view, please visit the journal online (http://dx.doi.org/10. 1136/jitc-2021-003850).

EvD and PHL contributed equally.

DXB and JK are joint senior authors.

Accepted 02 November 2021

Check for updates

(c) Author(s) (or their employer(s)) 2021. Re-use permitted under CC BY-NC. No commercial re-use. See rights and permissions. Published by BMJ.

${ }^{1}$ Center for Translational Immunology, University Medical Center Utrecht, Utrecht University, Utrecht, The Netherlands

${ }^{2}$ Department of Hematology, University Medical Center Utrecht, Utrecht University, Utrecht, The Netherlands

Correspondence to

Dr Jürgen Kuball;

J.H.E.Kuball@umcutrecht.nl

Eline van Diest, ${ }^{1}$ Patricia Hernández López, ${ }^{1}$ Angelo D Meringa, ${ }^{1}$ Anna Vyborova, ${ }^{1}$ Froso Karaiskaki, ${ }^{1}$ Sabine Heijhuurs, ${ }^{1}$ Jan Gumathi Bormin, ${ }^{1}$ Sanne van Dooremalen, ${ }^{1}$ Mara J T Nicolasen, ${ }^{1}$ Lucrezia C D E Gatti, ${ }^{1}$ Inez Johanna, ${ }^{1}$ Trudy Straetemans, ${ }^{1}$ Zsolt Sebestyén, ${ }^{1}$ Dennis X Beringer (i) , 1 Jürgen Kuball (D) ${ }^{1,2}$

\section{ABSTRACT}

Background $\gamma 9 \delta 2 \mathrm{~T}$ cells hold great promise as cancer therapeutics because of their unique capability of reacting to metabolic changes with tumor cells. However, it has proven very difficult to translate this promise into clinical success.

Methods In order to better utilize the tumor reactivity of $\gamma 9 \delta 2 \mathrm{~T}$ cells and combine this with the great potential of $\mathrm{T}$ cell engager molecules, we developed a novel bispecific molecule by linking the extracellular domains of tumorreactive $\gamma 9 \delta 2 T C R s$ to a CD3-binding moiety, creating gamma delta TCR anti-CD3 bispecific molecules (GABs). GABs were tested in vitro and in vivo for ability to redirect T lymphocytes to a variety of tumor cell lines and primary patient material.

Results GABs utilizing naturally occurring high affinity $\gamma 9 \delta 2$ TCRs efficiently induced $\alpha \beta T$ cell mediated phosphoantigen-dependent recognition of tumor cells. Reactivity was substantially modulated by variations in the V82 CDR3-region and the BTN2A1-binding HV4-region between CDR2 and CDR3 of the $\gamma$-chain was crucial for functionality. GABs redirected $\alpha \beta T$ cells against a broad range of hematopoietic and solid tumor cell lines and primary acute myeloid leukemia. Furthermore, they enhanced infiltration of immune cells in a 3D bone marrow niche and left healthy tissues intact, while eradicating primary multiple myeloma cells. Lastly, GABs constructed from natural high affinity $\gamma 9 \delta 2$ TCR sequences significantly reduced tumor growth in vivo in a subcutaneous myeloma xenograft model.

Conclusions We conclude that GABs allow for the introduction of metabolic targeting of cancer cells to the field of $T$ cell engagers.

\section{INTRODUCTION}

Among all immunological subtypes, $\gamma \delta \mathrm{T}$ cells stand out in an unbiased computational analysis for their association with improved overall survival of patients with many different tumor types. ${ }^{1} \gamma \delta \mathrm{T}$ cells are innate like T cells that are present in both blood and tissue and are known to be important for recognition of foreign pathogens, stress signatures of infected cells, and cancer cells. ${ }^{2}$ In vitro, $\gamma \delta \mathrm{T}$ cells display very potent and broad tumor recognition; they can target and lyse cancer cells of both hematological and solid origin. ${ }^{34}$ In contrast to $\alpha \beta$ T cells, $\gamma \delta$ T cells do not rely on HLA for target cell recognition. ${ }^{5}$ $\gamma 9 \delta 2 \mathrm{~T}$ cells, a $\gamma \delta$ subset mainly present in the blood, are known to recognize an increase in intracellular phosphoantigens (pAg), which can be caused by microbial infections but are also found in many cancers. ${ }^{6}$ Recognition of intracellular pAg levels by $\gamma 9 \delta 2 T C R s$ relies on an inside out mechanism involving RhoB, BTN3A1, and BTN2A1. ${ }^{7-11}$ The metabolic targeting of tumor cells by $\gamma 9 \delta 2 \mathrm{~T}$ cells paves the way for novel tumor antigens for immunotherapy. ${ }^{12}$ Unfortunately, the adoptive transfer of ex vivo expanded polyclonal $\gamma \delta \mathrm{T}$ cells associates so far with few clinical responses, ${ }^{13}$ most likely because of a significantly underestimated diversity, and many mechanisms of tolerance in advanced cancer patients that act against this particular immune subset. ${ }^{12} 14$ Most recently, restoring the $\alpha \beta / \gamma 9 \delta 2 \mathrm{~T}$ cell balance by BTN3A1 blocking antibodies has been suggested to hold great therapeutic promise as a new checkpoint inhibitor ${ }^{15}$; but only a fraction of tumors is infiltrated by $\gamma 9 \delta 2 \mathrm{~T}$ cells. ${ }^{1} \mathrm{~T}$ cells engineered to express a defined $\gamma \delta$ TCR (TEGs) have been proposed as an alternative strategy $^{11} 1^{16-24}$ in line with the development of chimeric antigen receptor transduced $\mathrm{T}$ cells (CAR-T). ${ }^{25} 26$ However, advanced therapy medicinal products (ATMPs) such as genetically engineered $\mathrm{T}$ cells are delivered to patients with a substantial price tag, ${ }^{27}$ and production processes, as well as clinical implementation are cumbersome. ${ }^{28}$

To avoid the practical and economic challenges of ATMPs while still using the immune 
system to attack cancer, an alternative strategy is currently employed for classical antigens like CD19. Bispecific antibodies (bsAb) have been developed, fusing a tumortargeting domain to a $\mathrm{T}$ cell binding domain, to recruit cytotoxic $\mathrm{T}$ cells to tumors. Such a bispecific $\mathrm{T}$ cell engager (BiTE) combining an anti-CD19 and anti-CD3 domain is now used in daily clinical practice, ${ }^{29}$ and many other $\mathrm{bsAb}$ for cancer immunotherapy are in various phases of clinical development. ${ }^{30}$ The selection of suitable tumorassociated target antigens for these novel therapies, however, remains very challenging, currently limiting the broad application of CAR-T and bsAb therapy. ${ }^{31}$

An alternative $\mathrm{T}$ cell engager strategy arose by linking the extracellular domain of an $\alpha \beta T C R$ as a tumor antigen binding domain to a single chain variable fragment $(\mathrm{scFv})$ of a CD3 antibody. ${ }^{32}$ These $\alpha \beta T C R-b i s p e c i f i c s$ recognize intracellular peptides presented by MHC molecules, creating the possibility of targeting novel tumor-specific antigens that are not expressed at the cell surface. HLA restriction, however, also limits the use of such $\alpha \beta T C R-$ bispecifics to tumors with high mutational loads and defined HLA-types. Furthermore, downregulation of HLA is observed as an immune-escape mechanism in approximately $40 \%-90 \%$ of all human tumors, ${ }^{33}$ thereby greatly limiting the applicability of therapies based on $\alpha \beta T C R$ mediated tumor recognition.

To overcome these limitations and to combine the tumor specificity and therapeutic potential of $\gamma \delta \mathrm{T}$ cells with the recent success of $\mathrm{T}$ cell engagers, we fused the extracellular domain of a $\gamma 9 \delta 2 \mathrm{TCR}$ to an anti-CD3 scFv. We demonstrate that these Gamma delta TCR Anti-CD3 Bispecific molecules (GABs) with natural high affinity r $982 T C R$ can mimic the rather complex more patternlike mode of action mediated by a $\gamma 9 \delta 2 \mathrm{TCR}^{7834}$ without the need of additional affinity maturation. GABs efficiently redirect $\alpha \beta T$ cells towards several tumor cell lines of both hematologic and solid origin, as well as primary patient material in vitro. Furthermore, we show significant reduction of tumor growth after GAB treatment in a subcutaneous myeloma xenograft model. We conclude that GABs open an avenue towards metabolic cancer targeting tumors with a bispecific format.

\section{METHODS}

\section{Generation of bispecific constructs}

A customized pcDNA3-NEO vector, which allows consecutive expression of two genes of interest under their own CMV promoter, was a kind gift of Jan Meeldijk (LTI protein facility, UMC Utrecht, The Netherlands). First, the anti-CD3 scFv (OKT3) ${ }^{35}$ gene was cloned into multiple cloning site one. In addition to the antiCD3-scFv gene, the DNA fragment also contained bases encoding, a $\left(\mathrm{G}_{4} \mathrm{~S}\right)_{3}$ flexible linker at the 5' end and poly histidine tag on the 3' end. At the 5' end of the flexible linker, a BsiWI restriction site was present for the subsequent introduction of the TCR gamma chain in the vector, resulting in the TCR $\gamma$-CD3scFv fusion gene. The TCR $\delta$-chain was cloned into the second multiple cloning site. TCR domain boundaries were used as in Allison et al. ${ }^{36}$ Most $\gamma 9$ - and $\delta 2$ TCR sequences were reported previously, ${ }^{11}{ }^{24} 36$ while other $\gamma \delta$ TCR sequences were obtained from randomly picked clones (table 1 ).

\section{Expression and purification of bispecifics}

His-tagged GABs were expressed in 293 F cells. 293 F cells were cultured in Gibco Freestyle Expression medium, as transfection reagent Polyethylenimine (PEI) $(25 \mathrm{kDa}$ linear PEI, Polysciences, Germany) was used. Transfection was done using $293 \mathrm{~F}$ cells at a density of $1.10^{6}$ cells/ $\mathrm{mL}$ mixed with $1.25 \mu \mathrm{g}$ DNA and $3.75 \mu \mathrm{g}$ PEI per million cells. DNA and PEI were premixed in freestyle medium (1/30 of transfection volume), incubated for $20 \mathrm{~min}$ and added dropwise to the cell cultures. The cultures were maintained shaking at $37^{\circ} \mathrm{C} 8 \% \mathrm{CO}_{2}$. Cell culture supernatant was harvested after 5 days and filtered through a $0.22 \mu \mathrm{m}$ filter top (Milipore, USA). Supernatant was adjusted to $25 \mathrm{mM}$ Tris (Sigma Aldrich, Germany), 150 $\mathrm{mM} \mathrm{NaCl}$ (Sigma Aldrich, Germany) and $15 \mathrm{mM}$ Imidazole (Merck, Germany) ( $\mathrm{pH}$ 8). Supernatant was loaded on a $1 \mathrm{~mL}$ HisTrap FF column (GE Healthcare, USA) using the ÄKTA start purification system (GE healthcare, USA). Column was washed with IMAC loading buffer (25 $\mathrm{mM}$ Tris, $150 \mathrm{mM} \mathrm{NaCl} 15 \mathrm{mM}$ Imidazole $(\mathrm{pH} 8)$, and protein was eluted using a linear imidazole gradient from 21 to $300 \mathrm{mM}$ in $20 \mathrm{CV}$. Fractions containing the GAB were pooled, concentrated and buffer exchanged to TBS (25 mM tris, $150 \mathrm{mM} \mathrm{NaCl}, \mathrm{pH}$ 8) using vivaspin $410 \mathrm{kD}$ spin columns (Sartorius, Germany). Protein was diluted 100 times in IEX loading buffer (25 mM Tris $\mathrm{pH} 8$ ), and loaded onto a HiTrap Q HP $1 \mathrm{~mL}$ column (GE healthcare, USA) using the ÄKTA start purification system, for a second purification step. Column was washed with 10 column volumes IEX loading buffer, and protein was eluted using a linear $\mathrm{NaCl}$ gradient form 50 to $300 \mathrm{mM}$ in $25 \mathrm{CV}$. Fractions containing the GAB were pooled, concentrated using vivaspin $410 \mathrm{kD}$ spin columns (Sartorius, Germany) and examined by SDS-PAGE and staining with Instant blue protein stain (Sigma Aldrich, Germany). Protein concentration was measured by absorbance on Nanodrop and corrected for the Extinction coefficients. Protein was snap frozen and stored at $-80^{\circ} \mathrm{C}$ and thawed before use.

Cell lines, flow cytometry, IFN $\gamma$ Elispot, CD107 degranulation assay, luciferase based cytotoxicity and the animal model are reported in online supplemental methods.

\section{In vitro bone-marrow model}

The 3D model was previously described in detail. ${ }^{20}$ In short: primary CD138+ were selected from the mononuclear cells (MNCs) of myeloma bone marrow from two patients by MACS separation using microbeads (Miltenyi Biotec, Germany). The CD138+ cells and the RPMI 8226 tumor cells were stained with Vybrant DiO (Thermo Fisher, USA) and seeded in Matrigel (Corning, USA) together with multipotent mesenchymal stromal 


\begin{tabular}{llll}
\hline Table 1 & GAB sequences & & \\
\hline GAB & Ref. & CDR3 $\delta$ & CDR3 $\gamma$ \\
\hline CL5 & 24 & CACDALKRTDTDKLIF & CALWEIQELGKKIKVF \\
6 2 & This report & CACDTLPGAGGADKLIF & CALWEVQELGKKIKVF \\
CL13 & 24 & CACVPLADTDKLIF & CALWEVIELGKKIKVF \\
G115 & 36 & CACDTLGMGGEYTDKLIF & CALWEAQQELGKKIKVF \\
AJ8 & This report & CACDTAGGSWDTRQMFF & CALWEAQQELGKKIKVF \\
A1 & 11 & CACDTLLLGDSSDKLIF & CALWEAQQELGKKIKVF \\
A3 & 11 & CACDAWGHTDKLIF & CALWEAQQELGKKIKVF \\
A4 & 11 & CACDALGDTGSDKLIF & CALWEAQQELGKKIKVF \\
C1 & 11 & CACDPVPSIHDTDKLIF & CALWEAQQELGKKIKVF \\
C3 & 11 & CACDTVSGGYQYTDKLIF & CALWEAQQELGKKIKVF \\
C4 & 11 & CACDTLALGDTDKLIF & CALWEAQQELGKKIKVF \\
C5 & 11 & CACDLLAPGDTSFTDKLIF & CALWEAQQELGKKIKVF \\
C7 & 11 & CACDMGDASSWDTRQMFF & CALWEAQQELGKKIKVF \\
LM1 & 24 & CACDTLLATDKLIF & CALWEAQQELGKKIKVF \\
DLC4 & 46 & CACDPAILGDELSWDTRQMFF & CALWEVRQELGKKIKVF \\
MOP & 38 & CACDPVVLGDTGYTDKLIF & CALKELGKKIKVF \\
RIG1 & 9 & CACDPVQVTGGYKVDKLIF & CALWEVHELGKKIKVF \\
RIG6 & 9 & CACDPLIGSERLGDTGIDKLIF & CALWESQELGKKIKVF \\
DGSF68 & 45 & CACDTVAHGGGTDKLIF & CALWEVGELGKKIKVF \\
\hline
\end{tabular}

Depicted are sequences used for generation of GABs.

GAB, gamma delta TCR anti-CD3 bispecific molecules.

cells (MSCs) and endothelial progenitor cells (EPCs), both stained with Vybrant DiD (Thermo Fisher, USA). After 4 days, $\mathrm{T}$ cells were stained with Vybrant DiI (Thermo Fisher, USA) and administered to the model together with CL5 or LM1 GAB $(30 \mu \mathrm{g} / \mathrm{mL})$ and $10 \mu \mathrm{M}$ PAM (Calbiochem, USA). One day later, the culture medium was refreshed with medium contaning $30 \mu \mathrm{g} /$ $\mathrm{mL}$ GAB. Tumor cells, $\mathrm{T}$ cells and stromal cells within and surrounding the matrigel were visualized 2 days later by confocal imaging. Afterwards, the Matrigel was dissolved using Dispase (Corning, USA) to retrieve the cells from the model. The cells were quantified by flow cytometry using Flow Count Fluorospheres (Beckman Coulter, USA) and normalized to mock treatment.

\section{RESULTS}

\section{Production of highly pure GABs}

In line with the observation that antibodies and high affinity $\alpha \beta T C R$ can be linked to anti-CD3scFvs to redirect $\mathrm{T}$ cells to tumor cells, ${ }^{32}$ we assessed whether the

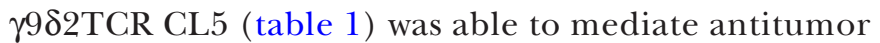
reactivity in a bispecific format. Gamma delta TCR Anti-CD3 Bispecific molecules (GABs) were cloned with an anti-CD3scFv derived from the anti-CD3 $\varepsilon$ antibody OKT3 linked to the $\mathrm{C}$ terminus of the gamma chain of a soluble $\gamma 9 \delta 2 \mathrm{TCR}$, using a flexible $\left(\mathrm{G}_{4} \mathrm{~S}\right)_{3}$ linker (figure 1A).
CL5 GAB was expressed in mammalian freestyle $293 \mathrm{~F}$ cells as secreted protein, and purified from the culture supernatant using His-tag purification, followed by a second ion exchange purification step, to ensure a highly pure protein product. As expected, the two different chains of the GAB, ectoGamma$\mathrm{CD} 3 \mathrm{scFv}$ and ectoDelta, were both clearly visible on gel (figure 1B). This indicates that during expression, the two separate chains of the GAB associate properly, resulting in a heterodimeric bispecific molecule.

\section{GABs bind to $\alpha \beta T$ cells}

To further address proper folding of GABs, we employed a flow cytometry based analysis. $\alpha \beta T$ cells were incubated with CL5 GAB, followed by a secondary staining using fluorochrome labeled antibodies against V $\delta 2, \mathrm{~V} \gamma 9$ or pan $\gamma \delta \mathrm{TCR}$ (figure 1C). A strong and specific staining could be observed with all three antibodies, further indicating that the CD3scFv and both TCR chains are properly associated and folded. Following GAB binding on the cell surface of $\mathrm{T}$ lymphocytes that were coated with CL5 GAB over time, shows GAB binding up to 4 days after initial binding to CD3 (figure 1D), with a declining signal after 2 days implying, as for other bispecific molecules, ${ }^{37}$ that continuous presence of the molecule will be needed to maintain efficacy. 
A

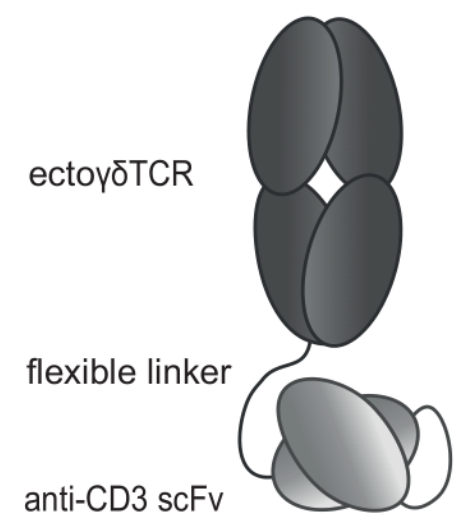

B

Figure $1 \mathrm{GAB}$ design and binding to $\mathrm{CD} 3+\mathrm{T}$ cells. (A) Schematic representation of the GAB design, showing the extracellular $\gamma \delta$ TCR domain linked to an anti-CD3 scFv via a flexible linker. (B) Purified GAB was run on SDS-page gel and stained with coomassie brilliant blue protein stain, visualizing the ecto $\gamma-C D 3 s c F v$ and ecto $\delta$-chain. (C,D) Coating of $\alpha \beta T$ cells with GAB $(10 \mu \mathrm{g} / \mathrm{mL}(\mathrm{C})$ or $90 \mu \mathrm{g} / \mathrm{mL}$ (D)), followed by staining with fluorochrome labeled anti-V $\gamma 9$, V $\delta 2$ or pan $\gamma \delta$ antibodies. MFI was measured by flow cytometry and represented in histograms. GAB, gamma delta TCR anti-CD3 bispecific molecules

\section{GABs induce $p A g$-dependent tumor recognition by $\alpha \beta T$ cells which is influenced by variations in the V 22 TCR chain} r982T cells are known to recognize SCC9 cells, a squamous cell carcinoma cell line. This recognition can be enhanced by treating tumor cells with pamidronate (PAM), which causes an increase in the intracellular phosphoantigen (pAg) levels by inhibiting the mevalonate pathway. ${ }^{24}$ To test whether GABs can also induce recognition of this cell line, $\alpha \beta$ T cells and SCC9 target cells were coincubated with and without PAM, and CL5 or LM1 GAB. LM1 GAB was generated to serve as negative control, LM1 GAB harbors a $\gamma 9 \delta 2 T C R$ where the CDR3 region of the $\delta$-chain is replaced by a single alanine, making the $\gamma 9 \delta 2 T C R$ non-functional. ${ }^{24}$ As anticipated, CL5-but not 
LM1 GAB, induced recognition of SCC9 target cells by $\alpha \beta T$ cell in the presence of PAM (figure $2 \mathrm{~A}$ ), suggesting that the mode of recognition by GABs is comparable to recognition mediated by $\gamma 9 \delta 2$ TCRs expressed at a cell membrane. ${ }^{11}$

$\mathrm{We}^{1124}$ and others ${ }^{38-40}$ reported on the impact of changes in the CDR3 region of 82 TCR chains on TCR function. To assess the impact of variations in the CDR3 region of the $\delta 2 \mathrm{TCR}$ chain on GAB activity, we generated a larger panel of GABs, derived from previously published $\gamma 9 \delta 2 \mathrm{TCRs}^{112436}$ and randomly picked $\gamma 9 \delta 2 \mathrm{~T}$ cell clones, varying in CDR3 $\delta$-chain (table 1). To assess activity, the different GABs were coincubated with $\alpha \beta T$ cells and SCC9 target cells in the presence of PAM. Most GABs efficiently induced an IFN $\gamma$ response, though activity substantially differed between different constructs (figure 2B), although all showed similar binding to $\alpha \beta$ $\mathrm{T}$ cells (online supplemental figure $\mathrm{S} 1$ ). GABs in which the CDR3 $\delta$ were reduced to one alanine (LM1) did not induce IFN $\gamma$ production at any concentration (figure 2B). Titrating GAB concentrations allowed for further analysis of the differences in efficacy between the different CDR $3 \delta$ sequences. We observed large differences in GAB activity with an $\mathrm{EC}_{50}$ of $0.8 \mu \mathrm{g} / \mathrm{mL}$ for the best performing $\mathrm{GAB}$ to an $\mathrm{EC}_{50}$ of $25 \mu \mathrm{g} / \mathrm{mL}$ for the lowest activity. $\mathrm{EC}_{50}$ of several non-active or very low active receptors could not formally be assessed (figure 2B and table 2).

\section{$\gamma$-TCR loop and BTN3A are critical for GAB mediated $\alpha \beta$ T cell activation}

The HV4 region between the CDR2 and the CDR3 of the $\gamma$-chain is critical for $\gamma 9 \delta 2 T C R$ activity by binding to BTN2A1 expressed on target cells. ${ }^{9-11}$ To assess whether GABs also depend on this mode of action, we focused on GAB CL5, one of the most active TCR sequences from the tested panel, and introduced two mutations in the $\gamma \mathrm{HV} 4$ region of CL5 GAB $\left(\mathrm{E}_{70} \mathrm{D}_{72} \rightarrow \mathrm{K}_{70} \mathrm{~L}_{72}\left(\mathrm{CL} 5_{\mathrm{EDKL}} \mathrm{GAB}\right)\right.$ and $\mathrm{H}_{85} \rightarrow \mathrm{R}_{85}\left(\mathrm{CL} 5_{\mathrm{HR}} \mathrm{GAB}\right)$ ), reported to cause loss of activity in membrane expressed $\gamma 9 \delta 2$ TCRs. ${ }^{41}$ CL5, CL5 $5_{\mathrm{EDKL}}$ and CL5 $5_{\mathrm{HR}}$ GABs were added to a coculture of $\alpha \beta T$ cells with the well-described breast cancer cell line (MDA-MB231) or multiple myeloma cell line (RPMI 8226) ${ }^{1124}$ in the presence of PAM. CL5 $5_{\mathrm{EDKL}}$ and CL5 $5_{\mathrm{HR}}$ GAB lost activity, assessed by IFN $\gamma$ production, when compared with the wild type CL5 GAB (figure 2C), highlighting the importance of the $\gamma \mathrm{HV} 4$ region for target cell engagement by GABs.

BTN3A has also been recognized as a crucial factor in phosphoantigen dependent $\gamma 9 \delta 2 \mathrm{TCR}$ reactivity. Loss of BTN3A membrane expression on target cell leads to a complete loss of membrane-bound $\gamma 9 \delta 2 \mathrm{TCR}$ reactivity to pAgs. ${ }^{11}{ }^{42}$ By testing GAB mediated recognition of HEK293FT WT and BTN3A knockout, we confirmed that GAB induced recognition after PAM treatment also depends on BTN3A expression (figure 2D). These findings support the assumption that there is a similar binding mode between membrane-expressed $\gamma 9 \delta 2 \mathrm{TCRs}$ and GABs, both depending on encounter of BTN2A1 through the $\gamma$-chain and a second signal, which is pAg and BTN3A depended.

\section{GABs retarget $\alpha \beta T$ cells to a wide variety of tumor cells}

Next, we addressed whether GABs can redirect $\alpha \beta T$ cells to a broader variety of tumor cells, and whether GABs with different $\mathrm{EC}_{50}$ against SCC9 target cells also have different activities against a broader range of hematological and solid tumor cells. GABs with lower (AJ8) and higher (CL5) $\mathrm{EC}_{50}$ or the negative control LM1 GAB were coincubated with $\alpha \beta T$ cells and previously defined panel of tumors targets cells. ${ }^{43}$ A significant increase in IFN $\gamma$ production was observed for CL5 and AJ8 GABs against most tumor targets except for HL60 and MDA-MB157, while LM1 GAB did not induce cytokine secretion (figure 2E). For most cell lines, CL5 GAB had a slightly higher activity compared with $\mathrm{AJ} 8 \mathrm{GAB}$, although not always significant. Isolated $\mathrm{CD} 4^{+}$and $\mathrm{CD} 8^{+} \alpha \beta \mathrm{T}$ cells induced IFN $\gamma$ release after coincubation with CL5 GAB (online supplemental figure S2A). However, as expected, we observed that the relative contribution of $\mathrm{CD}_{4}^{+}$and $\mathrm{CD} 8^{+} \alpha \beta \mathrm{T}$ cells differed between donors and target cells, with $\mathrm{CD}^{+} \alpha \beta \mathrm{T}$ cells producing more cytokines in general.

As in blood up to $5 \%$ of the $\mathrm{CD} 3^{+} \mathrm{T}$ lymphocytes

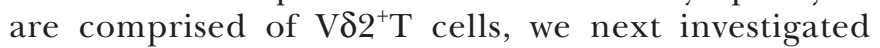
GAB activity in combination with $\mathrm{V} \delta 2^{+}$and $\alpha \beta \mathrm{T}$ cells side by side. $\mathrm{V} \delta 2+$ and $\alpha \beta \mathrm{T}$ cells were isolated from a healthy donor and IFN $\gamma$ release was measured after a coculture with two recognized (RPMI8226, SCC9) and one unrecognized cell line (ML-1) with and without CL5 GAB and in the absence or presence of PAM (online supplemental figure S2B). LM1 GAB was added as extra control to the $\mathrm{V} \delta 2^{+} \mathrm{T}$ cells. As expected, the $\mathrm{V} \delta 2^{+} \mathrm{T}$ cells alone recognized the positive target cell lines after PAM treatment; surprisingly however, this recognition was lower compared with $\alpha \beta T$ cells coincubated with CL5 GAB. Activity of $\mathrm{V} \delta 2^{+} \mathrm{T}$ cells was not blocked by the addition of the mock LM1 GAB, and addition of GAB CL5 did not lead to a further increase in activation of the $\mathrm{V} \delta 2+\mathrm{T}$ cells. These data imply that GABs will most likely not activate $\mathrm{V} \delta 2^{+} \mathrm{T}$ cells, which could be a consequence of the differ-

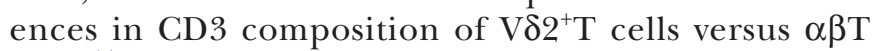
cells. ${ }^{44}$ This is also in line with the previous observation that $\mathrm{V} \delta 2^{+} \mathrm{T}$ cell expansion protocols usually do not use CD3 engagers, but rather rely on agents that directly engage the TCR, such as phytohaemagglutinin (PHA). ${ }^{4} 43$

To this point, IFN $\gamma$ production was used as a readout for GAB activity. However, the clinical activity of bispecific molecules comes through their ability to mediate killing of target cells. Therefore, as the next step, we assessed CD8 $+\alpha \beta$ T cell-mediated toxicity by using a degranulation assay detecting surface expression of the lysosomal-associate membrane glycoptrotein-1 (LAMP-1/CD107a) by flow cytometry (FC). $\alpha \beta$ T cells 
A

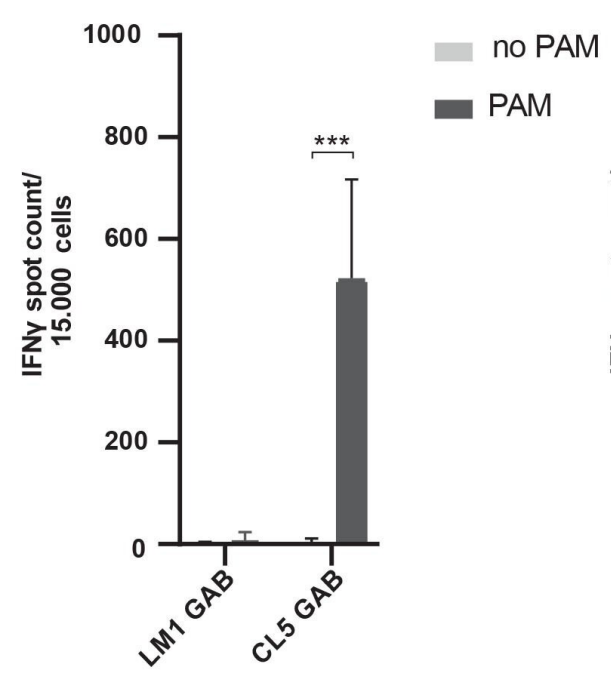

B

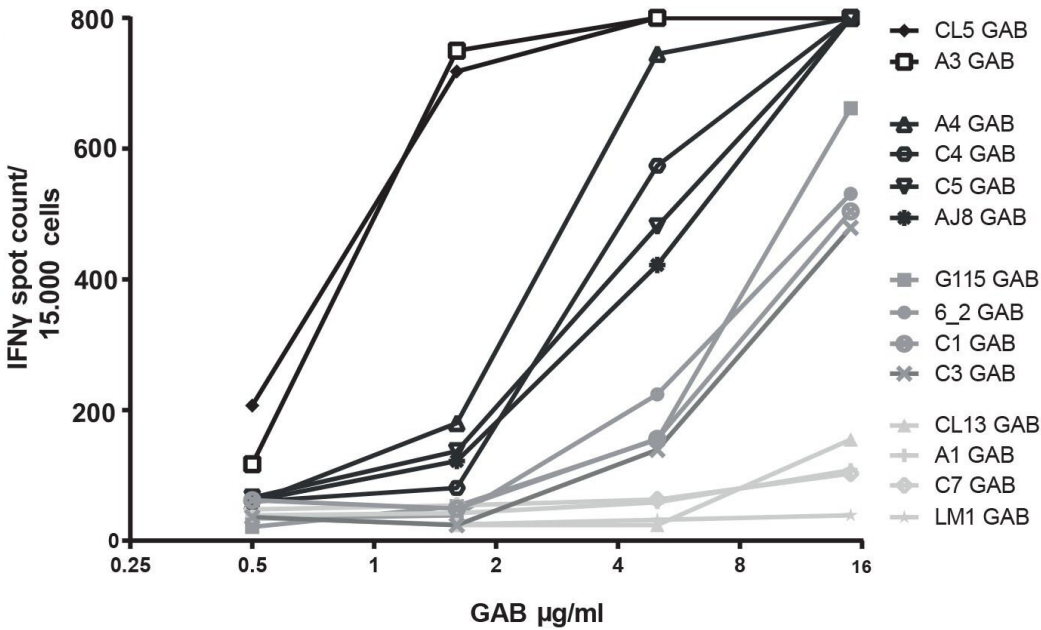

C

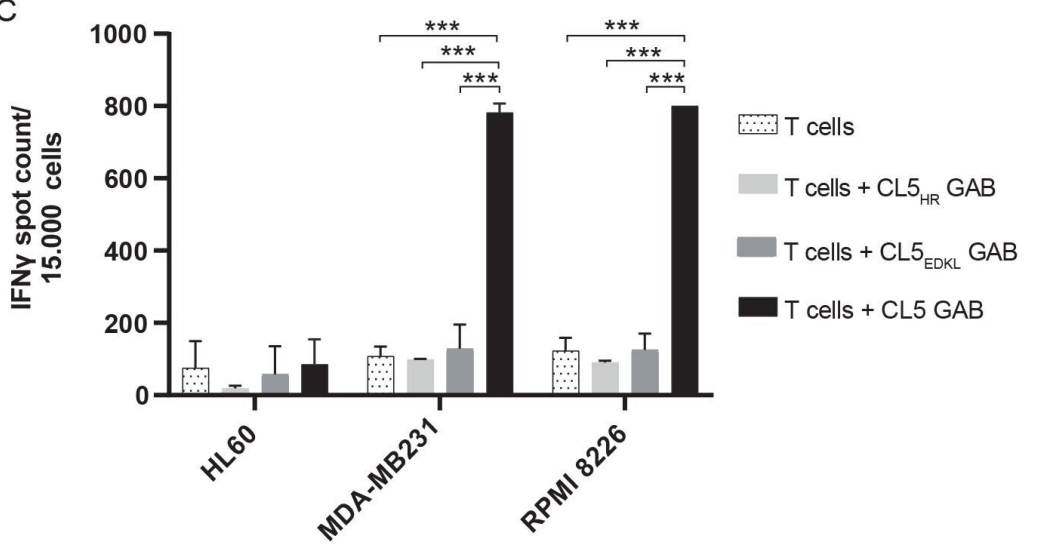

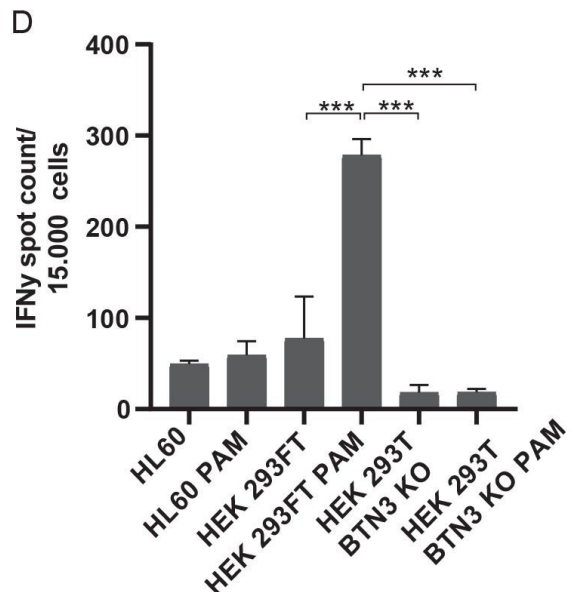

$\mathrm{E}$

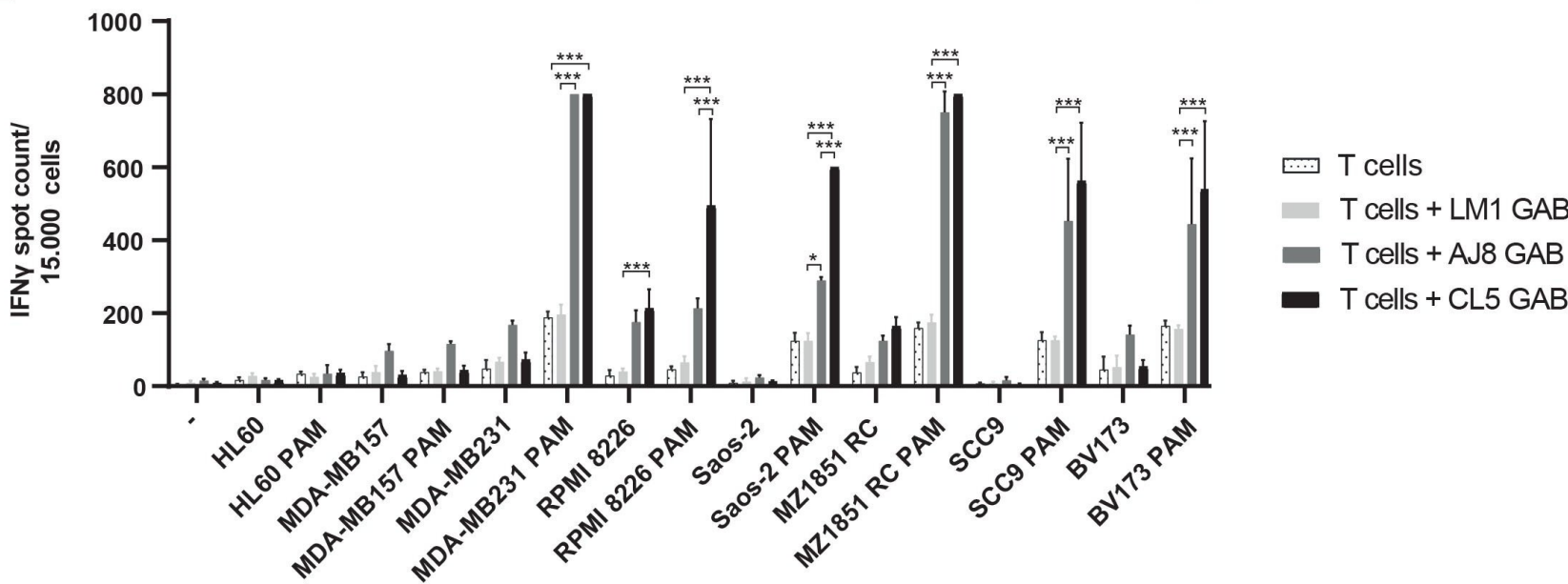

Figure 2 GABs induce pAg dependent tumor recognition by $\alpha \beta T$ cells. (A-E) IFN $\gamma$ production was measured by elispot, if separate spots could not be distinguished, spot count was set to a maximum value of 800 . (A) $\alpha \beta T$ cells were co-incubated with SCC9 target cells in the presence or absence of PAM $(100 \mu \mathrm{M})$ and LM1 or CL5 GAB $(10 \mathrm{ug} / \mathrm{mL})$, values are corrected for T cells only $(n=4)$. (B) T cells were incubated with SCC9 target cells, PAM $(100 \mu M)$ and an increasing concentration of GABs derived from different $\mathrm{V} \gamma$ 9V $\delta 2 T C R s$. A representative experiment is shown. (C) $\gamma$-chain HV4 mutations shown to hamper TCR binding were tested in the GAB format, $\alpha \beta T$ cells and target cells were co-incubated with the wildtype or mutant $\mathrm{GABs}(10 \mu \mathrm{g} / \mathrm{mL})$ and PAM $(100 \mu \mathrm{M}) \mathrm{n}=2$. (D) AJ8 GAB $(10 \mu \mathrm{g} / \mathrm{mL})$ was co-cultured with T lymphocytes, HL60, HEK293FT WT or BTN3A1 knockout cells with and without PAM $(100 \mu \mathrm{M}) \mathrm{n}=1$ in duplo. (E) CL5 and AJ8 GAB $(10 \mu \mathrm{g} / \mathrm{mL})$ were tested in a coculture of T cells and a larger panel of target cell lines with and without the addition of PAM $(100 \mu \mathrm{M})$, and compared with mock GAB LM1 $\mathrm{n}=2$. Error bars represent SD, significance was calculated using a multiple $T$ test $(A)$ or one-way ANOVA (C-E). ${ }^{*} P<0.05$, ${ }^{* \star} P<0.001$, ${ }^{* *} \mathrm{p}<0.0001$. ANOVA, analysis of variance; GAB, gamma delta TCR anti-CD3 bispecific molecules; PAM, pamidronate. 


\begin{tabular}{lcll}
\hline Table 2 & EC50 of GAB for IFN $\gamma$ release & & \\
\hline GAB & EC $_{50}(\boldsymbol{\mu g} / \mathbf{m L})$ & Cl $(\boldsymbol{\mu g} / \mathbf{m L})$ & $\mathbf{R}^{2}$ \\
\hline CL5 & 0.7524 & 0.6285 to 0.9086 & 0.9956 \\
\hline A3 & 0.8344 & 0.7055 to 0.9888 & 0.9637 \\
\hline A4 & 2.417 & 2.038 to 2.882 & 0.9851 \\
\hline C4 & 3.528 & 2.934 to 4.198 & 0.9916 \\
C5 & 4.028 & 3.304 to 4.818 & 0.9801 \\
\hline AJ8 & 4.586 & 3.816 to 5.444 & 0.9777 \\
G115 & 8.537 & 7.127 to 10.23 & 0.9923 \\
\hline $6 \_2$ & 9.811 & 7.777 to 12.17 & 0.9267 \\
C1 & 11.46 & 9.356 to 13.81 & 0.9471 \\
\hline C3 & 12.30 & 10.14 to 14.74 & 0.9740 \\
CL13 & 27.70 & 21.50 to 42.50 & 0.9301 \\
\hline A1 & n.d. & n.d. & n.d. \\
C7 & n.d. & n.d. & n.d. \\
LM1 & n.d. & n.d. & n.d. \\
\hline
\end{tabular}

EC50 of GABs was calculated from figure $2 A$.

GAB, gamma delta TCR anti-CD3 bispecific molecules; nd, not determined.

were cocultured with three different target cell lines and CL5, AJ8 or negative control LM1 GAB, with and without PAM for 7 hours (figure 3A). As an extra control, $\alpha \beta$ T cells and GABs were incubated together without target cells. Similar to the IFN $\gamma$ release data, GABs induced degranulation of CD8+ $\alpha \beta T$ cells on binding to a target cell line in a PAM dependent manner, while no upregulation of CD107a was observed when coincubated with the negative control cell line HL60. To formally assess the ability of GABs to kill tumor targets, we employed a luciferase-based cytotoxicity assay. RPMI 8226 and SCC9 tumor cells stably transduced with a luciferase gene were cocultured with GABs and $\alpha \beta T$ cells at different effector to target (E:T) ratios. After a coculture of 16 hours, the bioluminescence was measured by adding beetle luciferin to the coculture. The amount of viable cells was determined by comparing the bioluminescence signal to untreated target cells (figure 3B). Both CL5 and AJ8 GAB efficiently induced up to $60 \%-80 \%$ lysis of the tumor cells at the lower effector to target cell ratios, while LM1 GAB had as little activity as $\alpha \beta$ T cells alone.

To extend our findings to GABs harboring sequences published by others, ${ }^{9} 38456$ a second set of five GABs were generated (table 1) and tested for ability to induce target cell lysis after coincubation with $\alpha \beta \mathrm{T}$ lymphocytes and the multiple myeloma target cell line RPMI $8226^{11}$ in the presence of PAM. As benchmark, we used the previously identified GABs with lower (AJ8) and higher (CL5) $\mathrm{EC}_{50}$ and as negative control LM1 GAB. Again, we observed differences in activity, GABs harboring sequences from CL5 were superior to all other tested GABs. Only the GABs derived from DGSF68 and MOP TCR were not significantly different from the lysis induced by AJ8 GAB, while the other three tested GABs were inferior to the AJ8 GAB (online supplemental figure S3).

\section{GABs are active against primary leukemia but not against primary healthy tissues}

To test whether GABs can mediate recognition of primary tumors such as primary acute myeloid leukemia (AML), $\alpha \beta T$ cells were cocultured with AJ8 GAB and primary AML blasts of four patients, with and without PAM. GABs induced a significant increase in IFN $\gamma$ production on PAM treatment against two out of the four patient samples (figure 4A).

Given the broad activity of GABs, we next assessed their ability to sense healthy tissues in a resting or stressed situation. To this end, we isolated $\mathrm{B}$ cells, monocytes and CD34+ cells from a healthy donor, and tested reactivity of CL5 and LM1 GAB against these cells and against healthy donor-derived fibroblasts in an IFN $\gamma$ release assay. Recognition of the cells was tested in resting and also activated or stressed conditions, such as after irradiation or chemotherapy treatment. Neither CL5 nor LM1 GAB induced recognition of healthy cells, in resting, activated or stressed conditions, while the positive control, RPMI 8226 tumor cells, induced cytokine release when incubated with CL5 GAB (figure 4B).

\section{Favorable efficacy toxicity profile of GABs in the bone marrow niche}

In vivo, the tumor microenvironment is often important for survival and proliferation of tumor cells. Therefore, we tested whether GABs can also eradicate primary tumor material without harming healthy tissues in a more 
A

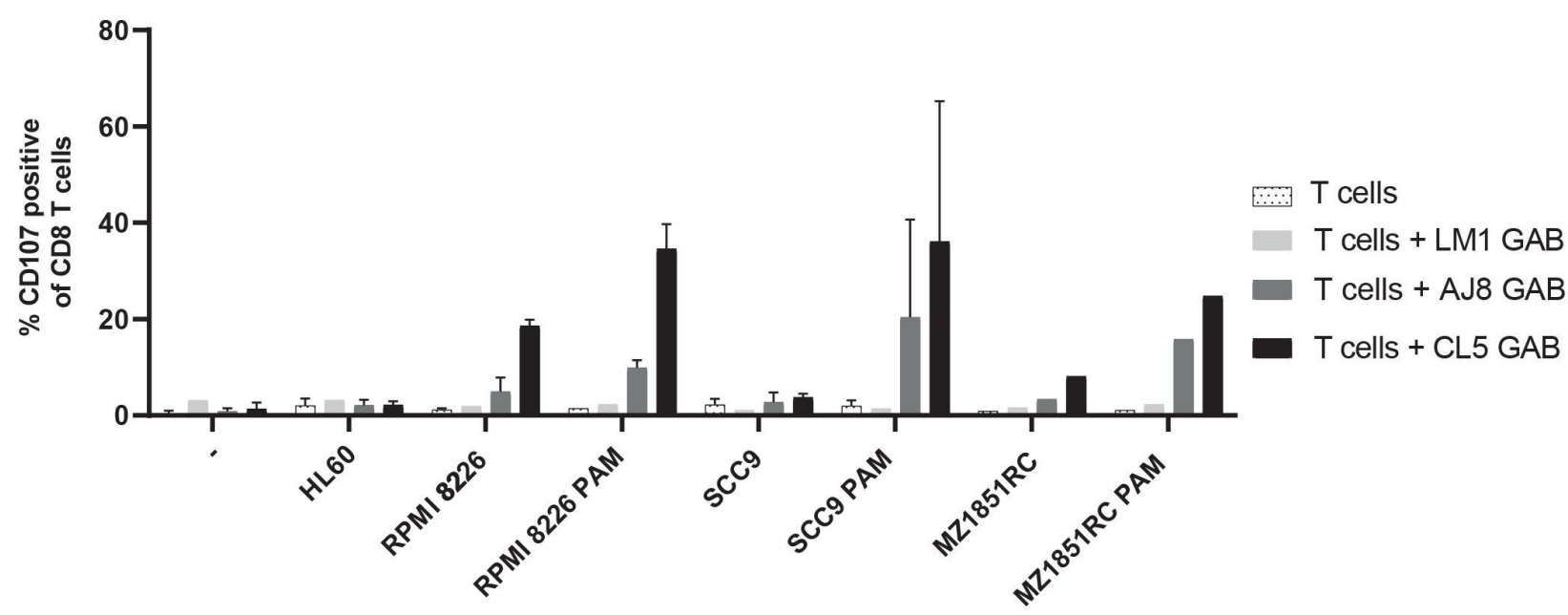

B
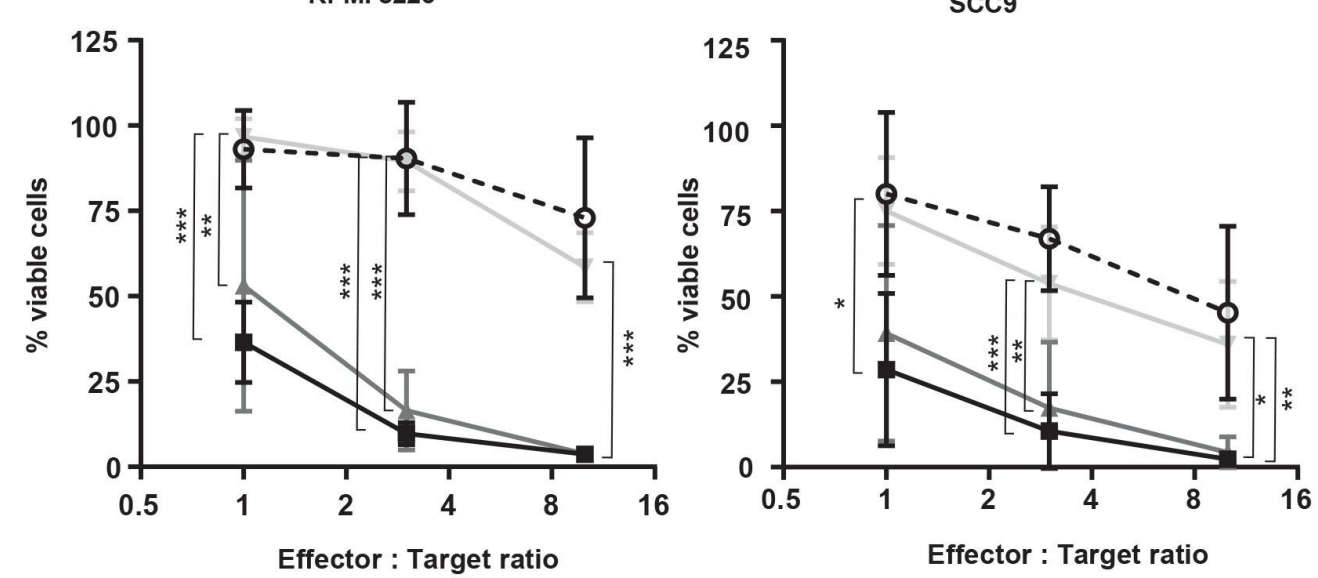

$-\Theta \cdot$ T cells

$\because$ T cells + LM1 GAB

$\neg T$ cells + AJ8 GAB

T cells + CL5 GAB

Figure 3 GABs induce T cell mediated lysis of cancer cell lines. (A) CD8+T cell degranulation was measured by staining with CD107a antibody during a 7-hour coincubation of T cell effector and three different target cell lines in the presence and absence of GAB $(10 \mu \mathrm{g} / \mathrm{mL})$ and PAM $(100 \mu \mathrm{M})$. Golgistop was added during the incubation. N=2 (for LM1 GAB and MZ1851RC N=1) significance was not calculated because of amount of data points. (B) T effector and luciferase transduced RPMI 8226 and SCC9 target cells were coincubated for 16 hours in the presence and absence of GAB $(10 \mu \mathrm{g} / \mathrm{mL})$ and PAM $(100 \mu M)$ at different $\mathrm{E}: T$ ratios. Percentage viable cells were determined by comparing luminescence signal to untreated target cells, representing $100 \%$ viability. $\mathrm{N}=3$, error bars represent $\mathrm{SD}$, significance was calculated using a one-way ANOVA. ${ }^{*} \mathrm{P}<0.05,{ }^{* *} \mathrm{p}<0.001$, ${ }^{* \star *} \mathrm{p}<0.0001$. ANOVA, analysis of variance; GAB, gamma delta TCR anti-CD3 bispecific molecules.

natural environment, using a previously described 3D bone marrow niche model ${ }^{20}$ In this model, mesenchymal stem cells (MSC) and endothelial progenitor cells (EPC) are used as stromal support for the growth of a multiple myeloma (MM) cell line (RPMI 8226) or primary CD138+ MM cells derived from patients. CD138+ MM cells from two patients, and the MM cell line RPMI 8226 were stained and seeded in matrigel together with MSCs and EPCs. After 4 days, labeled $\alpha \beta T$ cells, together with CL5 or LM1 GAB and PAM were added to the model. One day later, fresh medium with GABs was added to the model to ensure constant GAB coating on the $\alpha \beta T$ cells. After 2 days, visualizing $\alpha \beta T$ cells infiltrated into the tumor bearing matrigel by confocal microscopy indicated an increased $\alpha \beta \mathrm{T}$ cell infiltration in the presence of $\mathrm{Cl} 5$, but not LM1 GAB (figure 5A). This observation was supported by a subsequent FC based quantification of the $\alpha \beta T$ cells present in the matrigel (figure $5 \mathrm{~B}$ ). To further study specific $\alpha \beta T$ cell activation by GABs, we measured several cytokines in the supernatant of the 3D model containing primary MM tumor cells. Next to IFN $\gamma$, we also observed a significant increase in the levels of other Th1 cytokines, IL2 and TNF $\alpha$ for the CL5 GAB condition (figure 5C).

The most important measurement remains the elimination of tumor cells. Therefore, the amount of tumor cells remaining in the model after CL5 GAB treatment was determined by FC analysis and cell numbers were normalized to treatment with mock LM1 GAB. Treatment with CL5 GAB induced a signification reduction of CD138+ MM cells compared with the mock treatment with LM1 $\mathrm{GAB}$, for both patient samples and the MM cell line 
A

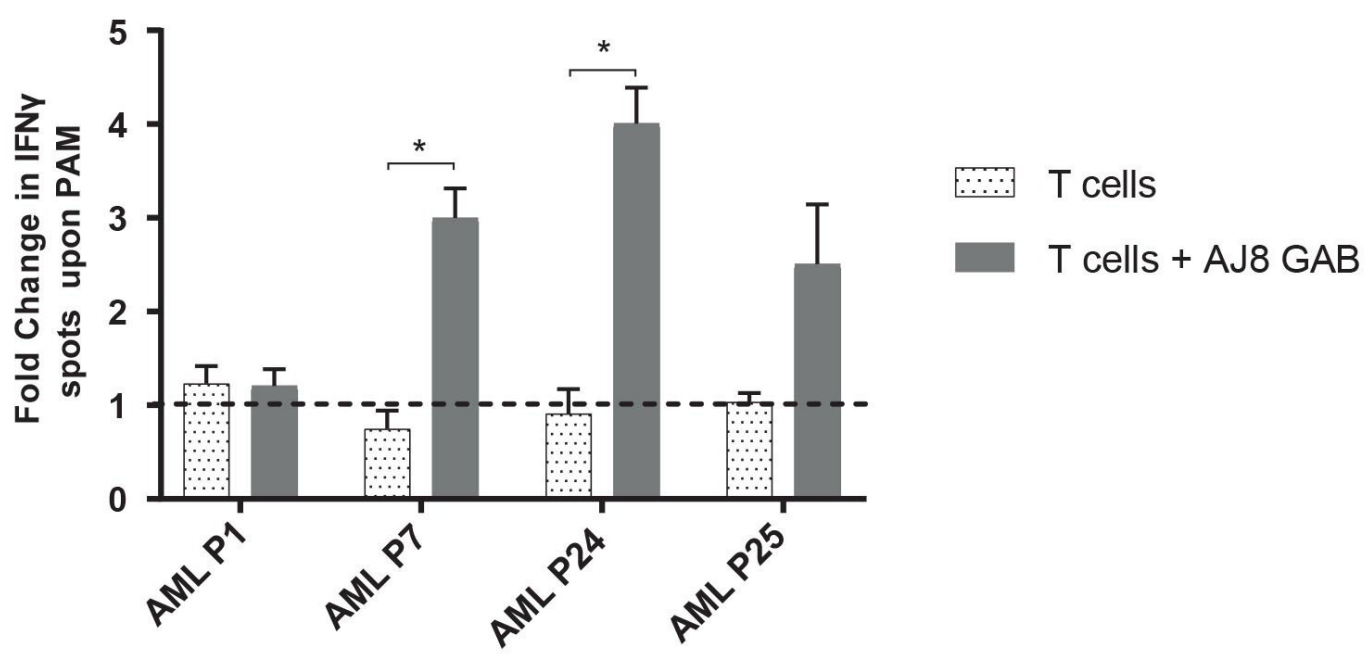

B

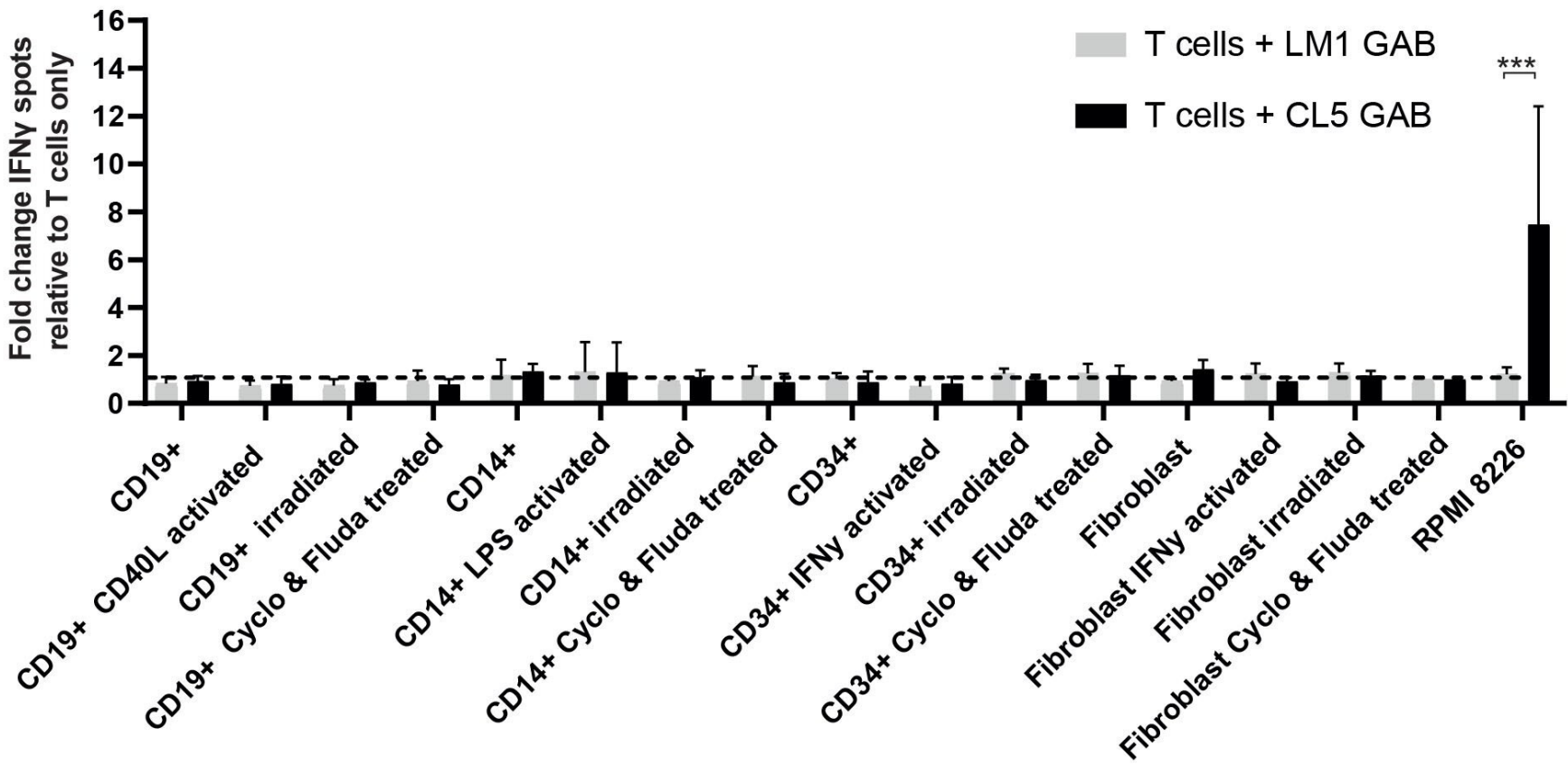

Figure 4 GABs induce recognition of primary AML samples but not of healthy hematopoietic cells or fibroblasts. (A) $\alpha \beta T$ cells were incubated with AML blasts with or without $100 \mu \mathrm{M}$ PAM, and $10 \mu \mathrm{g} / \mathrm{mL}$ AJ8 GAB. IFN $\gamma$ production was measured by elispot after 24 hours. Fold change in IFN $\gamma$ production on addition of pamidronate was calculated $N=1$. (B) $\alpha \beta T$ cells were cocultured with healthy hematopoietic cells or fibroblasts and LM1 or CL5 GAB $(10 \mathrm{ug} / \mathrm{mL})$. Target cells were activated as indicated, or stressed by irradiation or a combination treatment with cyclophosphamide (Cyclo) and fludarabine (Fluda). IFN $\gamma$ release was measured by elispot. The figure represents pooled data from four different target cell donors (CD19+ and CD14+) or two donors (CD34+ and fibroblasts). $\alpha \beta T$ effector cells were derived from four different donors (CD19+ and CD14+) or two donors (CD34+ and fibroblasts). Error bars represent SD, significance was calculated using a multiple $T$ test. ${ }^{*} \mathrm{P}<0.05$, ${ }^{* *} \mathrm{p}<0.001,{ }^{* \star *} \mathrm{p}<0.0001$. GAB, gamma delta TCR anti-CD3 bispecific molecules.

RPMI 8226 (figure 5D). Healthy stromal cells were also quantified, showing no differences between CL5 or LM1 GAB treatment (figure 5D), suggesting that surrounding healthy tissues are not affected by the treatment with active GAB.

\section{GABs control tumor growth in vivo}

To test whether treatment with GABs can also affect tumor growth in vivo, we established a xenograft model by injecting RPMI 8226 multiple myeloma cells subcutaneously (s.c) into NSG mice. For this in vivo experiment, we generated RPMI 8226 B2M knock-out cells that we injected s.c, as in previous experiments intravenously injected WT RPMI 8226 cells were rejected when coengrafted with human PBMC, most likely due to alloreactivity (online supplemental figure S4). One week after tumor cell injection, mice received an intravenous 
A
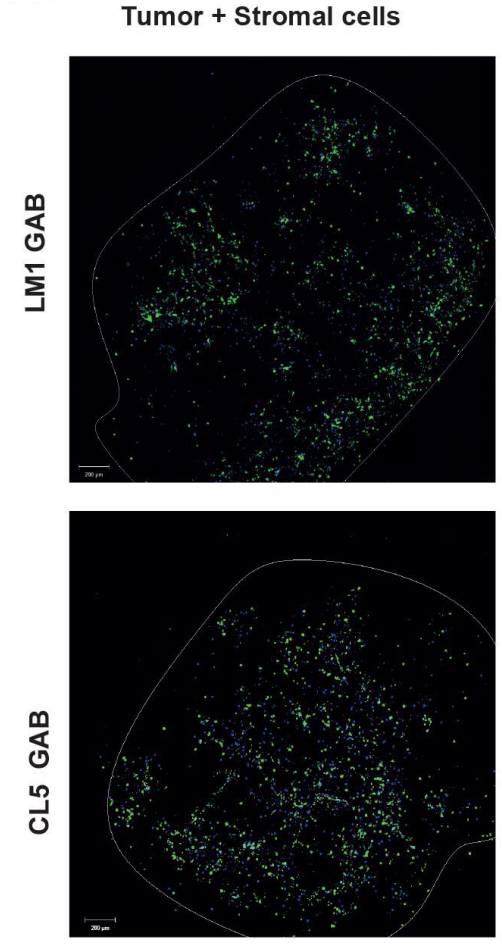

C
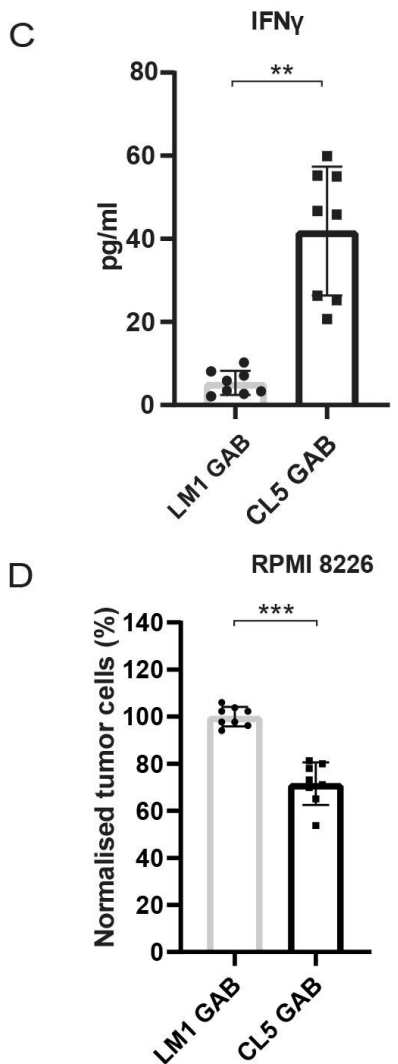
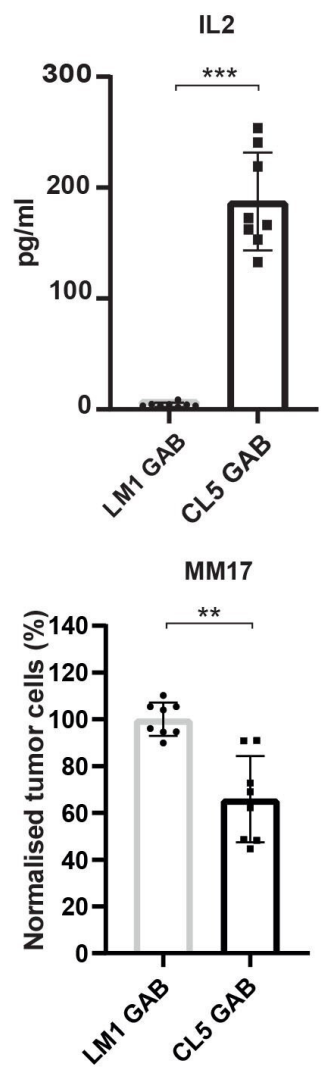

T cells
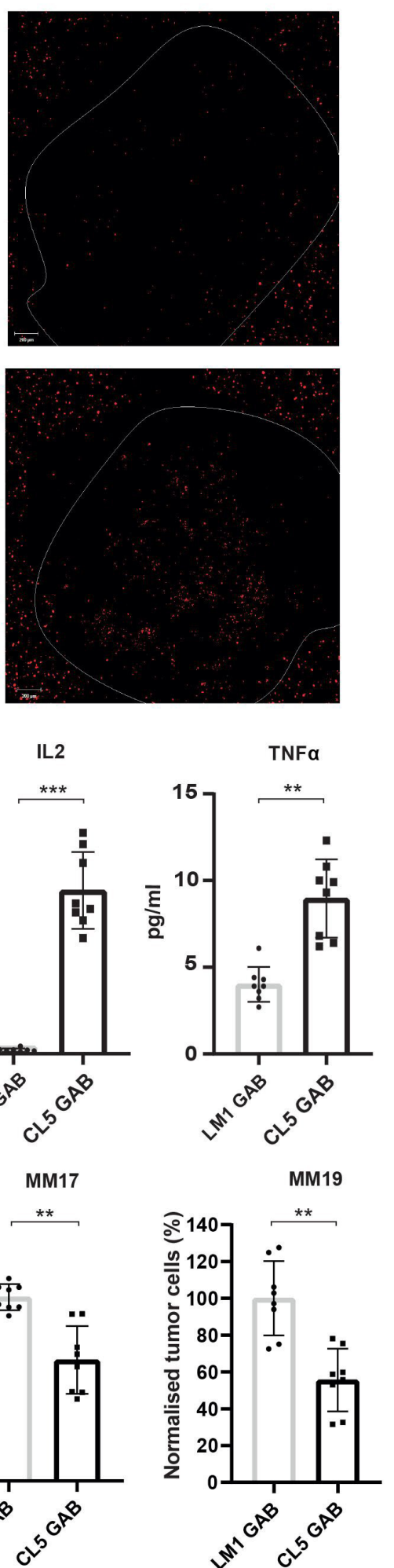

B

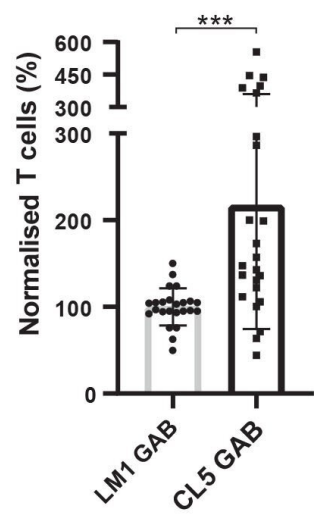

Figure 5 GABs mediate recognition and lysis of primary multiple myeloma in a 3D model. The RPMI 8226 tumor cell line or primary MM patient material was cultured in a 3D bone marrow niche consisting of matrigel and stromal cells. After 4 days, $\alpha \beta T$ cells were added together with PAM $(10 \mu \mathrm{M}$ PAM) and GAB $(30 \mu \mathrm{g} / \mathrm{mL})$. (A) Confocal images showing cell localization within and around the 3D model (boundaries indicated by the white line) with the tumor and stromal cells, respectively, in green and blue and T cells in red. (B) Two days after addition of the T cells, the matrigel was dissolved to retrieve the cells from the model. $\alpha \beta T$ lymphocytes were quantified by flow cytometry and normalized to mock treatment. (C) Cytokines were measured in the supernatant by luminex. (D) Tumor and stromal cells were collected from the dissolved matrigel and quantified by FC. Cell numbers were normalized to mock treatment. Significance was calculated by a paired T test. ${ }^{*} P<0.05,{ }^{* *} p<0.001,{ }^{* \star *} p<0.0001$. $\mathrm{N}=4$ with technical duplo's. GAB, gamma delta TCR anti-CD3 bispecific molecules 
injection of human PBMCs (figure 6A). Next, the mice were randomized over two groups, based on tumor size, and received treatment for seven consecutive days with CL5 GAB or the mock LM1 GAB. Moreover, an additional group in which mice received tumor and PBMCs but no GABs was included as extra control to monitor coengraftment of PBMCs and tumor in NSG mice. Tumor volume was measured three times per week for 30 days. Treatment with CL5 GAB significantly decreased tumor growth compared with the control group treated with LM1 GAB (figure 6B). Furthermore, mice treated with LM1 GAB showed similar tumor outgrowth compared with the PBMC only group. Persistence of GABs bound to $\alpha \beta$ T cells in the blood was determined by flow cytometry 1,2 and 8 days after GAB injection by calculating absolute number of $\alpha \beta T C R-$ and $\alpha \beta T C R / \gamma \delta$ TCR double positive (GAB coated) $\mathrm{T}$ cells. figure $6 \mathrm{C}$ shows that 24 hours after the first GAB injection (day 10) and 48 hours after the last GAB injection (day 17 ), around $30 \%$ of the total $\alpha \beta T C R$ positive cells are $\alpha \beta T C R / \gamma \delta$ TCR double positive, meaning that there are still GABs bound to the T cells. Furthermore, we found that 8 days after the last GAB injection (day 23), this double positive population was no longer present.

\section{DISCUSSION}

In this study, we developed a novel bispecific $T$ cell engager format, gamma delta TCR Anti-CD3 Bispecific molecules (GABs), based on the fusion of a soluble $\gamma 9 \delta 2 T C R$ to an anti-CD3 scFv. With GABs, we introduce the targeting of cancer as a metabolic disease to the field of bispecific $\mathrm{T}$ cell engagers. GAB activity against tumor but not healthy tissues was observed when using naturally occurring high affinity $\gamma 9 \delta 2 \mathrm{TCR}$ and relied, as for membrane bound r $9 \delta 2 T C R$, on the complex orchestration of BTN2A1 and BTN3A1 and was modified by intracellular phosphoantigen levels. ${ }^{811} 12$

Most $\mathrm{T}$ cell engagers use tumor targeting domains with binding affinities in the nanomolar range, a 10-100fold affinity maturation has been reported to further enhance activity. ${ }^{37} 47$ For $T$ cell engagers with an $\alpha \beta T C R$ as tumor binding domain, affinity maturation from the micromolar to picomolar range is needed to overcome the rather low overall avidity mediated by a low density of tumor associated molecules within the context of MHC molecules, in order to create functional T cell engagers. ${ }^{48}$ Therefore, it was initially surprising that a $\gamma 9 \delta 2 \mathrm{TCR}$ is active in the bispecific format without artificial affinity maturation, while natural $\alpha \beta$ TCR showed only a little activity. ${ }^{32}$ Most recent studies estimated the binding affinity of the $\gamma 9$ chain to BTN2A1 to be around $40 \mu \mathrm{M}^{9}$ which is in the range of $\alpha \beta$ TCRs ${ }^{49}$ However, the number of BTN2A1 molecules that are present on the cell surface for binding to the $\gamma 9$ TCR chain is most likely substantially higher compared with tumor associated antigens in HLA complexes, potentially generating a higher avidity for

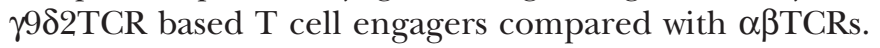

This however does not explain why, in our data set, only a selected group of defined $\gamma 9 \delta 2 T C R$ clones was active in the GAB format.

The reported affinity of the $\gamma 9$ chain to BTN2A1 (9) is presumably an underestimation of the binding affinity of the $\gamma 9 \delta 2 T C R$ to its complete interacting complex, as the TCR binding is not solely mediated by the $\gamma 9$-chain. This assumption is supported by our previous observation that apart from the $\gamma$-chain, variations in the CDR3 region of the $\delta 2$ chain also contribute substantially to the overall functional avidity of $\gamma 9 \delta 2$ TCRs once expressed in a $T$ cell. ${ }^{1124} \delta 2$ TCR sequences that were previously reported to mediate high overall efficacy when expressed at the cell membrane, ${ }^{11}$ also mediated high activity when used in the GAB format, for example, CL5 and A3. Vice versa, sequences which mediated lower efficacy in the TEG format were even poorer performers in the GAB format, for example, A1. Thus, as both the $\gamma 9$-chain and $\delta 2$-chain contribute to the affinity of a $\gamma 9 \delta 2$ TCR to its complex, a careful selection of $\delta 2 T C R$ sequences is needed guarantee a functional GAB.

Transforming cold into hot tumors is a key success factor for immune therapies. ${ }^{50}$ Novel $\alpha \beta T C R$ based biologics have been reported to warm 'cold' tumors. ${ }^{51}$ By using a 3D bone marrow niche model for primary MM cells, ${ }^{20}$ we provide evidence that $\gamma 9 \delta 2 \mathrm{TCR}$, when provided in the GAB format, can initiate infiltration of immune cells into the tumor microenvironment. This was further confirmed by the in vivo model, showing that GABs can reduce tumor growth of a subcutaneously growing RPMI 8226 tumor.

Furthermore, as the used 3D model was comprised of healthy MSC and EPC to guarantee survival and proliferation of MM cells in vitro, ${ }^{20}$ this model also allowed us to assess the impact of GABs on healthy tissues and extended our in vitro safety data for GAB. These current data confirm the previously reported lack of toxicity of targeting BTN2A1 and BTN3A1 when using a high affinity $\gamma 9 \delta 2 T C R$ in the TEG format ${ }^{17} 202324$ or when administering BTN3A1 targeting antibodies. ${ }^{15}$

In this report, we tested the reactivity of GABs to patient material from several patients with AML and found that GABs were reactive to two out of the four samples. This observation is in line with our previous report assessing larger tumor panels, including 16 patients with AML, which suggest that approximately $50 \%$ of all tumor cells are recognized by primary $\gamma \delta \mathrm{T}$ cells or TEGs. ${ }^{52}$ Mode of action studies investigating requirements for $\gamma 9 \delta 2 \mathrm{TCR}$ mediated tumor cell recognition, conducted in order to elucidate this differential tumor recognition, pointed to multiple factors such as $\mathrm{pAg}$ dependent rearrangement of the BTN2-BTN3 complex involving RhoB and the intracellular B30.1 domain of BTN3A1 (9-11). However, these studies also imply that a yet to be defined second ligand, binding to the CDR3 $\delta$ is most likely involved. Thus, although a lot of knowledge has been obtained over the past years, tumor recognition mediated by a $\gamma 9 \delta 2 T C R$ cannot be fully explained and predicted yet. ${ }^{11}$ Therefore, 
A

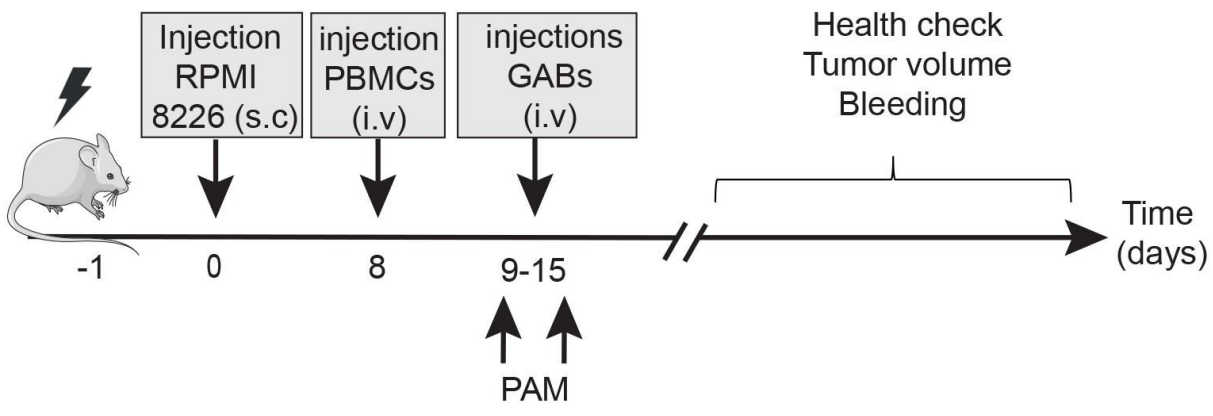

B

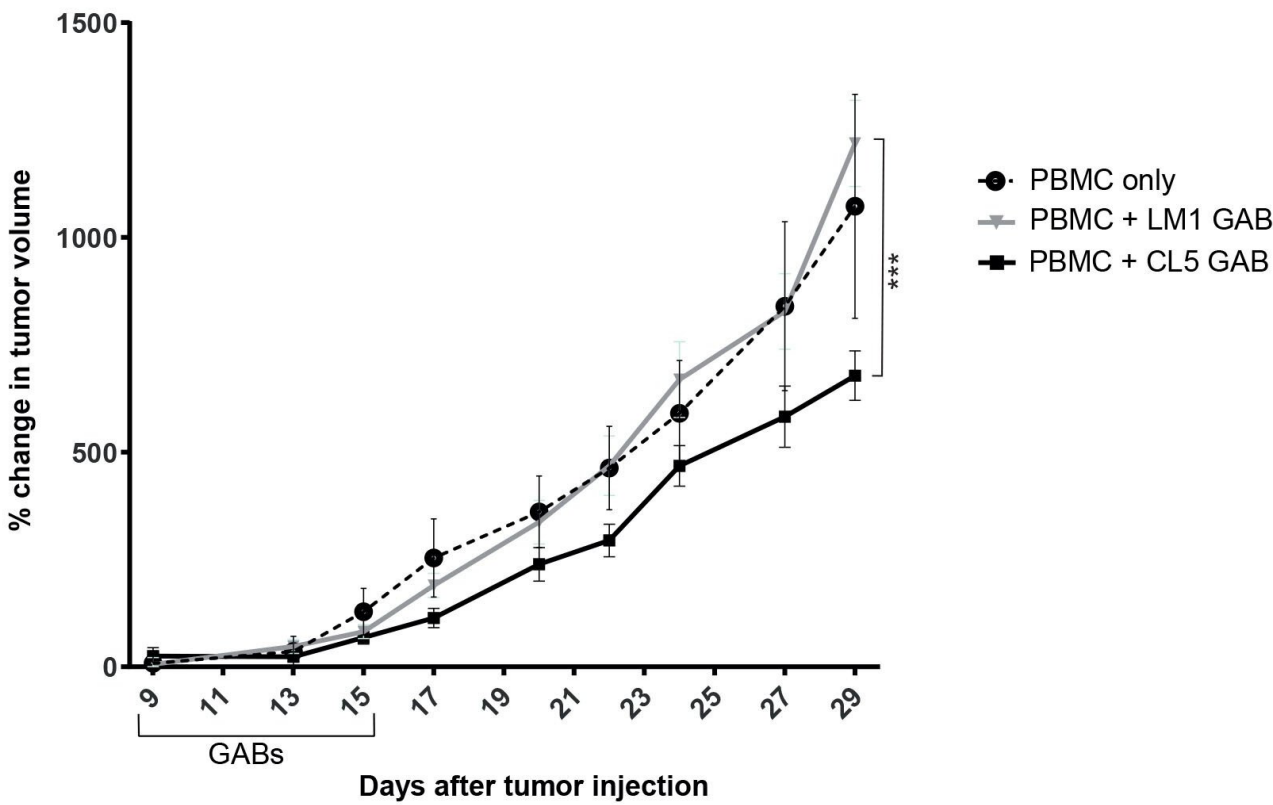

C
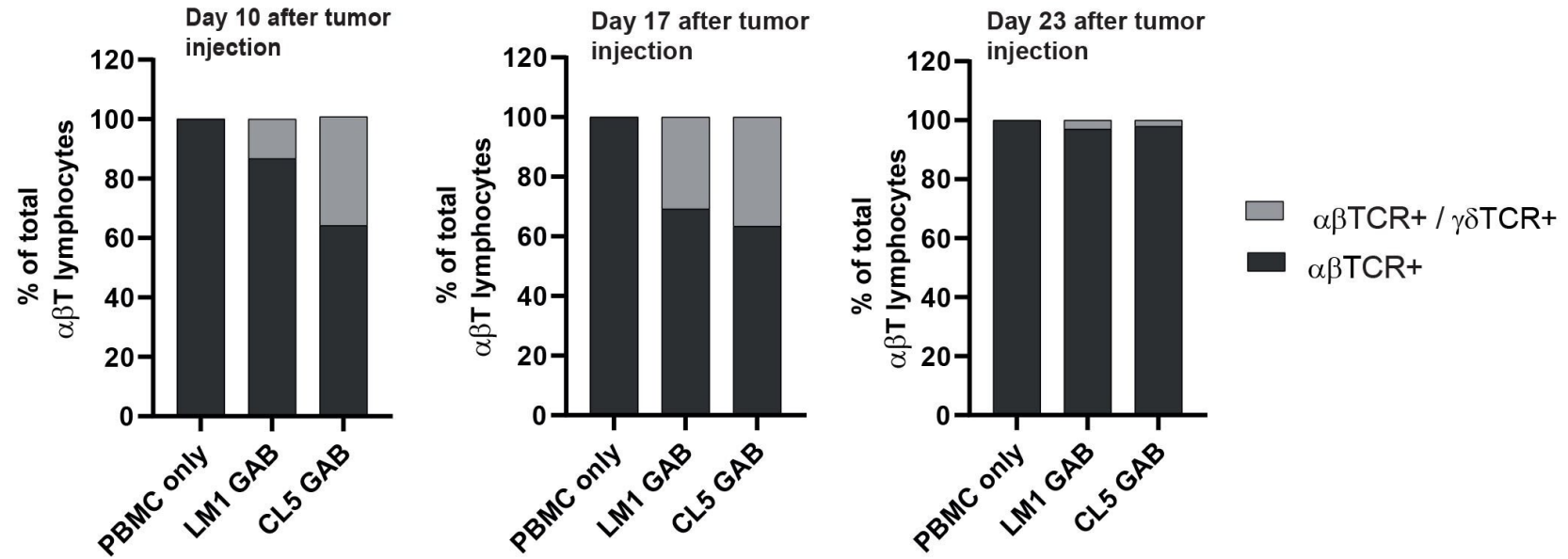

Figure 6 In vivo control of tumor growth by GABs. (A) Schematic representation of experimental design. NSG mice were irradiated at day -1 , and injected subcutaneous (s.c) with $10^{*} 10^{6}$ RPMI 8226 tumor cells 1 day later. After 7 days, the mice were randomized over three groups, based on tumor size $(\mathrm{N}=10)$. From day 9 to 15 , mice in two groups were treated with one intravenous injection per day of CL5 or LM1 GAB $(2,7 \mathrm{mg} / \mathrm{kg})$. Tumor size was measured three times per week for 3 weeks after start of the GAB treatment (B) and is plotted as percent change in tumor volume compared with the initial tumor volume at the start of the GABs treatment. (C) Amount of $\alpha \beta T C R$ single positive and $\alpha \beta T C R / \gamma \delta T C R$ double positive cells in the mice was determined by flow cytometry on day 10,17 and 23 after tumor injection, which corresponds to 24 hours after the first GAB injection and 48 hours and 8 days after the last GAB injection. Data are shown as mean of percentage of total $\alpha \beta T C R$ positive cells. PBMC only $\mathrm{N}=4$, LM1/CL5 GAB N=10. Error bars represent $\mathrm{SEM}$, significance was calculated by mixed-effects model with repeated measures. ${ }^{\star} \mathrm{P}<0.05,{ }^{\star *} \mathrm{p}<0.001,{ }^{* \star *} \mathrm{p}<0.0001$. GAB, gamma delta TCR anti-CD3 bispecific molecules. 
further investigation into the complex $\gamma 9 \delta 2$ TCR mediated target cell recognition, and the identification of novel biomarkers that can help identifying patient populations that are susceptible to $\gamma \delta$ based therapies will be key for a successful clinical translation. ${ }^{12}$

The GAB format outperformed natural $\gamma 9 \delta 2 \mathrm{~T}$ cells, as reported previously for TEGs, ${ }^{11}{ }^{43}$ most likely reflecting the careful selection of a high affinity $\gamma 9 \delta 2 T C R$ in the GAB or TEG design. Despite this superior activity, a limiting factor for $\gamma 9 \delta 2 \mathrm{TCR}$ mediated target cell recognition remains the requirement for $\mathrm{pAg}$ accumulation, also GAB mediated recognition of many cancer cells required additional treatment with amino-bisphosphonates to increase pAg levels. To elucidate why tumor cells differ in the dependence on PAM to enhance $\gamma 9 \delta 2 \mathrm{TCR}$ recognition further investigation will be needed, but it is most likely a consequence of different availabilities of all the characterized key components for $\gamma 9 \delta 2 \mathrm{TCR}$ binding, including, but not limited to, the intracellular accumulation of pAgs. The dependence on increased intracellular pAg levels for recognition of many tumors does however imply that $\gamma 9 \delta 2 \mathrm{TCR}$ based therapeutic strategies most likely need to be combined with amino-bisphosphonate treatment, a state of the art drug safely combined with many different treatments including $\gamma 9 \delta 2 \mathrm{~T}$ infusions. ${ }^{12}$

In conclusion, we have shown that a $\gamma 9 \delta 2 \mathrm{TCR}$ bispecific format can mimic the rather complex metabolic cancer targeting usually mediated by membrane bound r982TCR, ${ }^{7834}$ though requires a very careful selection of the used sequences and then allows for the introduction of the unique tumor targeting potential of $\gamma 9 \delta 2 \mathrm{~T}$ cells to the field of bispecific $T$ cell engagers. Our findings imply also that, in contrast to previously reported data for $\alpha \beta T C R$ derived bispecifics, selecting an endogenously occurring high affinity $\gamma 9 \delta 2 \mathrm{TCR}$ for use in a bispecific format could omit the need for affinity maturation. Since the use of affinity matured TCRs poses the risk of altering the TCR specificity or introducing cross-reactivity, ${ }^{53} 54$ using a therapy based on the endogenous TCR affinity could be a preferred strategy. This approach might overcome cumbersome engineering efforts and provide with GABs and TEGs, two complementary or even additive strategies as reported for CAR-T and bsAbs ${ }^{55}$ to harvest the potential of the new universe of targets extracted from $\gamma \delta \mathrm{T}$ cells.

Correction notice This article has been corrected since it was first published. The Abstract section has now been added.

Contributors EvD, DB, and JK wrote the paper. EvD, PHL, AM, AV, EK, SH, JGB, $\mathrm{SvD}, \mathrm{MN}, \mathrm{LG}, \mathrm{IJ}, \mathrm{TS}, \mathrm{ZS}$, and DB performed experiments. JK is guarantor. All authors approved the final manuscript.

Funding We thank the staff of the Flow Core Facility and the Multiplex Core Facility at the UMC Utrecht. We kindly thank Professor Erin Adams (The University of Chicago) for providing the CD277 KO HEK293T cell line and Halvard Boenig (Institute for Transfusion Medicine and Immunohematology, Goethe University, Frankfurt a. M., Germany) for providing feeder cells. Funding for this study was provided by ZonMW 43400003 and VIDI-ZonMW 917.11.337, KWF 2013-6426, 2014-6790 2015-7601, 2018-11393, 2018-11979, 2020-13403 to JK, KWF 2018-11393 2020-13403 to ZS, KWF 11979 and Marie Curie 749010 to DB.
Competing interests JK is shareholder of Gadeta (www.gadeta.nl). JK, ZS, DB, AV, and EvD are authors on the following patent applications: 2013: W0 2013 /147606 A1 Combinatorial gamma 9 delta $2 \mathrm{~T}$ cell receptor chain exchange, (C. Grunder, JK); 2017: 20170319674 Use of antibodies for enrichment of engineered $t$ cells with exogenous immune receptors and antibodies for use in depletion of engineered $t$ cells (JK) ; 2017: W0/2017/2017/212074 Novel method for identifying delta T cell (or gamma T cell) receptor chains or parts thereof that mediate antitumor or antiinfectious response (JK and colleagues; 2017: WO/2017/212072 Human leukocyte antigen restricted gamma delta T cell receptors (JK and colleagues), 2017/ 62508807 (ZS \& JK) Composition and methods for cell targeting therapies; 2018/ 6044506 (EvD, DB, JK): GABs as next generation of immune therapy

Patient consent for publication Not applicable.

Provenance and peer review Not commissioned; externally peer reviewed.

Data availability statement Data sharing not applicable as no datasets generated and/or analyzed for this study.

Supplemental material This content has been supplied by the author(s). It has not been vetted by BMJ Publishing Group Limited (BMJ) and may not have been peer-reviewed. Any opinions or recommendations discussed are solely those of the author(s) and are not endorsed by BMJ. BMJ disclaims all liability and responsibility arising from any reliance placed on the content. Where the content includes any translated material, BMJ does not warrant the accuracy and reliability of the translations (including but not limited to local regulations, clinical guidelines, terminology, drug names and drug dosages), and is not responsible for any error and/or omissions arising from translation and adaptation or otherwise.

Open access This is an open access article distributed in accordance with the Creative Commons Attribution Non Commercial (CC BY-NC 4.0) license, which permits others to distribute, remix, adapt, build upon this work non-commercially, and license their derivative works on different terms, provided the original work is properly cited, appropriate credit is given, any changes made indicated, and the use is non-commercial. See http://creativecommons.org/licenses/by-nc/4.0/.

\section{ORCID iDs}

Dennis X Beringer http://orcid.org/0000-0002-5986-1134

Jürgen Kuball http://orcid.org/0000-0002-3914-7806

\section{REFERENCES}

1 Gentles AJ, Newman AM, Liu CL, et al. The prognostic landscape of genes and infiltrating immune cells across human cancers. Nat Med 2015;21:938-45.

2 Bonneville M, O'Brien RL, Born WK. Gammadelta T cell effector functions: a blend of innate programming and acquired plasticity. Nat Rev Immunol 2010;10:467-78.

3 Scheper W, Gründer C, Straetemans T, et al. Hunting for clinical translation with innate-like immune cells and their receptors. Leukemia 2014;28:1181-90.

4 Scheper W, van Dorp S, Kersting S, et al. $\gamma \delta$ T cells elicited by CMV reactivation after allo-SCT cross-recognize CMV and leukemia. Leukemia 2013;27:1328-38.

5 Simões AE, Di Lorenzo B, Silva-Santos B. Molecular determinants of target cell recognition by human $\gamma \delta$ T cells. Front Immunol 2018;9:929.

6 Gober H-J, Kistowska M, Angman L, et al. Human T cell receptor gammadelta cells recognize endogenous mevalonate metabolites in tumor cells. J Exp Med 2003;197:163-8.

7 Gu S, Sachleben JR, Boughter CT, et al. Phosphoantigen-induced conformational change of butyrophilin 3A1 (BTN3A1) and its implication on Vgamma9Vdelta2 T cell activation. Proc Natl Acad Sci U S A 2017;114:E7311-20.

8 Sebestyen Z, Scheper W, Vyborova A, et al. RhoB mediates phosphoantigen recognition by Vgamma9Vdelta2 T cell receptor. Cell Rep 2016;15:1973-85.

9 Rigau M, Ostrouska S, Fulford TS, et al. Butyrophilin 2A1 is essential for phosphoantigen reactivity by gammadelta $T$ cells. Science2020;367.

10 Karunakaran MM, Willcox CR, Salim M, et al. Butyrophilin-2A1 directly binds germline-encoded regions of the Vgamma9Vdelta2 TCR and is essential for phosphoantigen sensing. Immunity 2020;52:487-98.

11 Vyborova A, Beringer DX, Fasci D, et al. $\gamma 9 \delta 2 T$ cell diversity and the receptor interface with tumor cells. J Clin Invest 2020;130:4637-51.

12 Sebestyen Z, Prinz I, Déchanet-Merville J, et al. Translating gammadelta $(\gamma \delta)$ T cells and their receptors into cancer cell therapies. Nat Rev Drug Discov 2020;19:169-84. 
13 Deniger DC, Moyes JS, Cooper LJN. Clinical applications of gamma delta T cells with multivalent immunity. Front Immunol 2014;5:636.

14 Scheper W, Sebestyen Z, Kuball J. Cancer immunotherapy using $\gamma \delta \mathrm{T}$ cells: dealing with diversity. Front Immunol 2014;5:601.

15 Payne KK, Mine JA, Biswas S. BTN3A1 governs antitumor responses by coordinating alphabeta and gammadelta T cells. Science 2020;369:942-9.

16 Johanna I, Hernandez-Lopez P, Heijhuurs S, et al. TEG011 persistence averts extramedullary tumor growth without exerting offtarget toxicity against healthy tissues in a humanized HLA-A*24:02 transgenic mice. J Leukoc Biol 2020;107:1069-79.

17 Johanna I, Straetemans T, Heijhuurs S, et al. Evaluating in vivo efficacy - toxicity profile of TEG001 in humanized mice xenografts against primary human $A M L$ disease and healthy hematopoietic cells. J Immunother Cancer 2019;7:69.

18 Kierkels GJJ, Scheper W, Meringa AD, et al. Identification of a tumorspecific allo-HLA-restricted $\gamma \delta$ TCR. Blood Adv 2019;3:2870-82.

19 Straetemans T, Janssen A, Jansen K, et al. TEG001 insert integrity from vector producer cells until medicinal product. Mol Ther 2020;28:561-71.

20 Braham MVJ, Minnema MC, Aarts T, et al. Cellular immunotherapy on primary multiple myeloma expanded in a 3D bone marrow niche model. Oncoimmunology 2018;7:e1434465.

21 Straetemans T, Kierkels GJJ, Doorn R, et al. GMP-grade manufacturing of $\mathrm{T}$ cells engineered to express a defined $\gamma \delta \mathrm{TCR}$. Front Immunol 2018;9:1062.

22 Kierkels GJJ, Straetemans T, de Witte MA, et al. The next step toward GMP-grade production of engineered immune cells. Oncoimmunology 2016;5:e1076608.

23 Straetemans T, Gründer C, Heijhuurs S, et al. Untouched GMP-ready purified engineered immune cells to treat cancer. Clin Cancer Res 2015;21:3957-68.

24 Grunder C, van DS, Hol S. gamma9 and delta2CDR3 domains regulate functional avidity of $\mathrm{T}$ cells harboring gamma9delta2TCRs. Blood 2012;120:5153-62.

25 June CH, O'Connor RS, Kawalekar OU, et al. Car T cell immunotherapy for human cancer. Science 2018;359:1361-5.

26 Singh AK, McGuirk JP. Car T cells: continuation in a revolution of immunotherapy. Lancet Oncol 2020;21:e168-78.

27 Chabannon C, Kuball J, Mcgrath E, et al. CAR-T cells: the narrow path between hope and bankruptcy? Bone Marrow Transplant 2017:52:1588-9.

28 McGrath E, Chabannon C, Terwel S, et al. Opportunities and challenges associated with the evaluation of chimeric antigen receptor T cells in real-life. Curr Opin Oncol 2020;32:427-33.

29 Batlevi CL, Matsuki E, Brentjens RJ, et al. Novel immunotherapies in Iymphoid malignancies. Nat Rev Clin Oncol 2016;13:25-40.

30 Krishnamurthy A, Jimeno A. Bispecific antibodies for cancer therapy: a review. Pharmacol Ther 2018;185:122-34.

31 Abbott RC, Cross RS, Jenkins MR. Finding the keys to the CAR: identifying novel target antigens for $\mathrm{T}$ cell redirection immunotherapies. Int J Mol Sci 2020;21:515.

32 Liddy N, Bossi G, Adams KJ, et al. Monoclonal TCR-redirected tumor cell killing. Nat Med 2012;18:980-7.

33 Bubeník J. Tumour MHC class I downregulation and immunotherapy (review). Oncol Rep 2003;10:2005-8.

34 Sandstrom A, Peigné C-M, Léger A, et al. The intracellular B30.2 domain of butyrophilin $3 \mathrm{~A} 1$ binds phosphoantigens to mediate activation of human V $\gamma 9 \mathrm{~V} \delta 2$ T cells. Immunity 2014;40:490-500.

35 Arakawa F, Kuroki M, Kuwahara M, et al. Cloning and sequencing of the $\mathrm{VH}$ and $\mathrm{V}$ kappa genes of an anti-CD3 monoclonal antibody, and construction of a mouse/human chimeric antibody. J Biochem 1996;120:657-62.

36 Allison TJ, Winter CC, Fournié JJ, et al. Structure of a human gammadelta T-cell antigen receptor. Nature 2001;411:820-4.

37 Goebeler M-E, Bargou RC. T cell-engaging therapies - BiTEs and beyond. Nat Rev Clin Oncol 2020;17:418-34.

38 Starick L, Riano F, Karunakaran MM, et al. Butyrophilin 3A (BTN3A CD277)-specific antibody 20.1 differentially activates $\vee \gamma 9$ V $\delta 2$ TCR clonotypes and interferes with phosphoantigen activation. Eur J Immunol 2017:47:982-92.

39 Wang H, Fang Z, Morita CT. Vgamma2Vdelta2 T cell receptor recognition of prenyl pyrophosphates is dependent on all CDRs. $J$ Immunol 2010;184:6209-22.

40 Yamashita S, Tanaka Y, Harazaki M, et al. Recognition mechanism of non-peptide antigens by human gammadelta T cells. Int Immunol 2003;15:1301-7.

41 Willcox CR, Vantourout P, Salim M, et al. Butyrophilin-like 3 Directly Binds a Human $\mathrm{V} \gamma 4^{+} \mathrm{T}$ Cell Receptor Using a Modality Distinct from Clonally-Restricted Antigen. Immunity 2019;51:813-25.

42 Harly C, Guillaume Y, Nedellec S, et al. Key implication of CD277/ butyrophilin-3 (BTN3A) in cellular stress sensing by a major human $\gamma \delta$ T-cell subset. Blood 2012;120:2269-79.

43 Marcu-Malina V, Heijhuurs S, van Buuren M, et al. Redirecting $\alpha \beta$ T cells against cancer cells by transfer of a broadly tumor-reactive $\gamma \delta \mathrm{T}$ cell receptor. Blood 2011;118:50-9.

44 Morath A, Schamel WW. $\alpha \beta$ and $\gamma \delta$ T cell receptors: Similar but different. J Leukoc Biol 2020;107:1045-55.

45 Tanaka Y, Morita CT, Tanaka Y, et al. Natural and synthetic nonpeptide antigens recognized by human gamma delta $T$ cells. Nature 1995;375:155-8.

46 De Libero G, Casorati G, Giachino C, et al. Selection by two powerful antigens may account for the presence of the major population of human peripheral gamma/delta T cells. J Exp Med 1991;173:1311-22.

47 Ellerman D. Bispecific T-cell engagers: towards understanding variables influencing the in vitro potency and tumor selectivity and their modulation to enhance their efficacy and safety. Methods 2019;154:102-17.

48 Li Y, Moysey R, Molloy PE, et al. Directed evolution of human T-cell receptors with picomolar affinities by phage display. Nat Biotechnol 2005;23:349-54.

49 Birnbaum ME, Mendoza JL, Sethi DK, et al. Deconstructing the peptide-MHC specificity of T cell recognition. Cell 2014;157:1073-87.

50 Duan Q, Zhang $\mathrm{H}$, Zheng J, et al. Turning cold into hot: firing up the tumor microenvironment. Trends Cancer 2020;6:605-18.

51 Lowe KL, Cole D, Kenefeck R, et al. Novel TCR-based biologics: mobilising T cells to warm 'cold' tumours. Cancer Treat Rev 2019;77:35-43.

52 Straetemans T, Gründer C, Heijhuurs S, et al. Untouched GMPReady purified engineered immune cells to treat cancer. Clin Cancer Res 2015;21:3957-68.

53 Riley TP, Baker BM. The intersection of affinity and specificity in the development and optimization of T cell receptor based therapeutics. Semin Cell Dev Biol 2018;84:30-41.

54 Cameron BJ, Gerry AB, Dukes J, et al. Identification of a titin-derived HLA-A1-presented peptide as a cross-reactive target for engineered MAGE A3-directed T cells. Sci Trans/ Med 2013;5:197ra03.

55 Choi BD, Yu X, Castano AP, et al. CAR-T cells secreting BiTEs circumvent antigen escape without detectable toxicity. Nat Biotechnol 2019;37:1049-58. 


\section{Correction: Gamma delta TCR anti-CD3 bispecific molecules (GABs) as novel immunotherapeutic compounds}

van Diest E, Hernández López P, Meringa AD, et al. Gamma delta TCR anti-CD3 bispecific molecules (GABs) as novel immunotherapeutic compounds. J Immunother Cancer 2021;9:e003850. doi:10.1136/jitc-2021-003850.

This article has been corrected since it was first published. The Abstract section has now been added.

Open access This is an open access article distributed in accordance with the Creative Commons Attribution Non Commercial (CC BY-NC 4.0) license, which permits others to distribute, remix, adapt, build upon this work non-commercially, and license their derivative works on different terms, provided the original work is properly cited, appropriate credit is given, any changes made indicated, and the use is non-commercial. See http://creativecommons.org/licenses/by-nc/4.0/.

(C) Author(s) (or their employer(s)) 2021. Re-use permitted under CC BY-NC. No commercial re-use. See rights and permissions. Published by BMJ.

J Immunother Cancer 2021;9:e003850corr1. doi:10.1136/jitc-2021-003850corr1

D) Check for updates 